\title{
Erythromycin Topical Cream
}

National Cancer Institute

\section{Source}

National Cancer Institute. Erythromycin Topical Cream. NCI Thesaurus. Code C78834.

A topical cream formulation containing the broad-spectrum macrolide antibiotic erythromycin with anti-bacterial activity. Erythromycin interacts with the $50 \mathrm{~S}$ subunit of the bacterial 70S ribosomal RNA complex resulting in the inhibition of protein synthesis and bacterial cell death. 